УДК 347.62

\title{
ПОНЯТИЕ И ПРАВОВАЯ ПРИРОДА ИМУЩЕСТВЕННЫХ ПРАВООТНОШЕНИЙ СУПРУГОВ
}

\section{Сербин Михаил Викторович} вице-президент Молодежного союза юристов Российской Федерации, заведующий кафедрой государственного права, кандидат юридических наук, доцент ФГАОУ ВО «Санкт-Петербургский государственный университет аэрокосмического приборостроения»

Сербина Лейла Арифовна

Старший преподаватель кафедры гражданского права ФГАОУ ВО «Санкт-Петербургский государственный университет аэрокосмического приборостроения»

\begin{abstract}
Аннотация: В статье рассматриваются основные подходы к понятию и правовой природе имущественных правоотношений супругов. Имущественные отношения супругов представляют собой правоотношения людей, находящихся в браке, по поводу собственности, приобретенной до брака или во время брака.
\end{abstract}

Ключевые слова: понятие, имущественные правоотношения, имущество супруги.

\section{THE CONCEPT AND LEGAL NATURE OF PROPERTY RELATIONS BETWEEN SPOUSES}

\section{Serbin Mikhail Viktorovich Serbina Leila Arifovna}

\begin{abstract}
: the article considers the main approaches to the concept and legal nature of property legal relations between spouses. Property relations of spouses are the legal relations of people who are married, regarding property acquired before marriage or during marriage.
\end{abstract}

Key words: concept, property relations, property of the spouse. 
Одну из важнейших категорий общественных отношений, которые регламентируются Гражданским и Семейными кодексами Российской Федерации, представляют имущественные отношения супругов. Следует сказать, что имущественные отношения между супругами обладают характерной для них спецификой. Зачастую супруги сталкиваются с такой проблемой, как заблаговременное определение имущественных прав, свобод и обязанностей $[6$, с.86]. Как известно, гражданское и семейное законодательство занимается данными проблемами, поскольку в соответствии со статьей 38 Конституции РФ семья находится под защитой государства [4].

Для определения понятия имущества нужно обратиться к формулировке, данной законодателем. Так, раскрывая юридический термин «имущество», необходимо упомянуть, что данное понятие пользуется большой популярностью, в частности в ГК РФ. Однако, даже при таком частом употреблении данного понятия до сегодняшнего дня термин «имущество»не получил законодательного закрепления. Зачастую данный термин используется для урегулирования и контроля определенных гражданских правоотношений, в которых имущество играет основную роль. В любом случае можно сказать, что понятие имущества представляет собой объект гражданского права.

Согласно ГК РФ к таким объектам гражданских прав можно отнести все имущество, имущественные права граждан, денежные средства, ценные бумаги, а также работы, услуги, результат интеллектуальной деятельности (в том числе интеллектуальная собственность) и некоторые другие [1].

Можно утверждать, что семейное законодательство повторяет некоторые положения и принципы гражданского законодательства. Однако, как правило, характеристика совместной собственности основывается на понятии нажитого имущества. Именно эта характеристика имущества находит свое отражение в нормах семейного законодательства, а не гражданского.

В Российской Федерации, как правило, общая собственность супругов регулируется законным режимом имущества. Однако, данный режим будет действовать в случае, если между супругами не был заключен брачный договор, который по своей природе меняет законный режим имущества на договорный [3, с.58].

Деление объектов гражданских прав на законодательном уровне предусматривает то, что само понятие имущества представляет собой особый 
вид объектов, которые находятся отдельно от других категорий гражданских прав. Как правило, в данное понятие включается все имущество супругов, в частности имущественные права, свободы и обязанности, если они применяются в ходе распоряжения общей собственностью [2, с.52].

В соответствии со статьей 244 Гражданского кодекса РФ совместная собственность - это общая собственность, где отдельные доли супругов определить невозможно, то есть не является раздельной собственностью.

Общая собственность представляет собой собственность нескольких лиц (в данном случае супружеской пары) на все имущество. Таким образом, супруги пользуются, распоряжаются и владеют этим имуществом, если иное не предусмотрено брачным договором.

Иными словами, совместная собственность представляет собой совместно нажитое имущество супругов в период брака. Согласно статье 34 СК РФ в совместно нажитому имущество входят:

- Денежные средства супругов, полученные от трудовой, предпринимательской деятельности (заработные платы, премии и так далее) и результатов интеллектуальной собственности (гонорар и другие);

- Денежные средства супругов, представляющие собой различные пенсии, пособия и другие социальные выплаты.

Вышеперечисленный перечень положений, относящихся к совместно нажитому имуществу супругов, не является законченным, поскольку законодатель дал неограниченный перечень вещей, которые могут входить в понятие имущества. Именно это служит одной из причин отсутствия понятия имущества на законодательном уровне.

Однако, денежные выплаты, не обладающие никаким особым целевым назначением по своей природе, не могут относиться к совместно нажитому имуществу супругов.

Что касается общих долгов супругов, то в соответствии со ст. 39 СК РФ они делятся пропорционально их долям, иными словами, здесь можно говорить о том, что общие долги супругов могут составлять совместно нажитое имущество.

Так, если супруг-заемщик взял в кредит денежные средства, к примеру, чтобы приобрести квартиру в интересах этой супружеской пары, то это имущество мгновенно переходит в такой правовой режим как совместное имущество супругов, и, как следствие, по долгам супруга отвечает каждый из супружеской пары. 
Также для защиты имущественных прав и обязанностей супругов в Семейном кодексе устанавливается право на совместное имущество неработающего супруга. Однако данные нормы будут действовать, если у супруга есть на то весомые причины и обстоятельства, например, декрет по уходу за ребенком, ведение домашнего хозяйства и некоторые другие основания.

Согласно ст. 36 СК РФ каждый из супругов помимо совместной собственности может иметь личное имущество, как правило, либо полученное в дар во время брака либо приобретенное до заключения брака, которым он может распоряжаться единолично.

Такое имущество можно разделить на 3 разновидности:

- Добрачное имущество, иными словами, имущество, приобретенное одним из супругов до вступления в брак;

- Использование в целях приобретения имущества на безвозмездной основе, к таким гражданско-правовым сделкам можно отнести такие договоры, как наследования, дарения и другие;

- Индивидуальное имущество каждого из супругов, а именно вещи индивидуального пользования.

Что касается зарубежный стран, в данном случае действует большее количество правовых режимов имущества супругов, чем в России:

- Режим общности представляет собой режим, при котором супруги имеют право общей собственности на имущество, которое было приобретено во время брака, но в то же время, супруги имеют право личной собственности на имущество, приобретенное до заключения брака или полученное в дар. В данном случае регулирование имущественных отношений супругов в зарубежных странах и в России очень похоже. Рассматриваемый режим, как правило, регулирует имущественные права супругов в европейских странах, таких как Испания, Италия, Франция, Бельгия, Португалия, а также некоторые штаты США. Так, например, Гражданский кодекс Италии устанавливает законный имущественный режим супругов, который выражается в праве общей собственности на имущество, в случае если между супругами не был заключен брачный договор. Однако, особенностью данного режима в Италии выступает то, что доходы супругов содержаться в специальном «остаточном» фонде, который считается раздельным, но оно делиться между супругами на равные части в случае расторжения брака между супругами. 
Во Франции общим имуществом супругов является все имущество, которое было приобретено ими за время их брака, однако сюда не относится имущество, которое было передано им по договору дарения или в качестве наследства. И в случае их развода, имущество, которое находилось у супругов в личном владении, т. е то которое они получили в дар или по наследству останется за ними, если порядок его использования не был прописан ими в брачном договоре [5, с.230].

- Режим отложенной общности можно охарактеризовать пользованием супругами имуществом раздельно, однако имущество подлежит объединению и равному разделу при разводе супругов. Этот режим существует в некоторых Скандинавских странах, таких как Норвегия, Швеция, Дания, а также Швейцария и некоторые другие. В некоторых странах супруги имеют право выбрать наиболее подходящий способ раздела - денежная компенсация, часть денежных средств равная приросту имущества за время брака или раздел имущества в натуральном виде. Прирост представляет собой разницу стоимости всего имущества на момент заключения брака и после его расторжения.

- Режим раздельной общности - это режим, при котором каждый супруг владеет своим добрачным имуществом, а также имуществом, приобретенным им во время брака. Данный режим характерен для таких стран, как Германия, Великобритания и некоторые другие. В первую очередь, такой режим указывает на равенство между мужчиной и женщиной, находящихся в браке, поскольку такой режим не дает права одному супругу пользоваться, владеть и распоряжаться имуществом другого супруга, а также он не допускает ограничений в отношении чьего-либо имущества. Однако во всех странах есть свои особенности и специфика пользования данным режимом. Так, например, в Германии при увеличении стоимости имущества, которое было приобретено уже во время брака одним из супругов, это имущество будет подлежать разделу в случае развода.

Необходимо подробнее остановиться на разновидностях правовых режимов имущества супругов в США. Здесь, как правило, регулирование имущественных отношений между супругами и их режим напрямую зависит от оснований заключенного брака. Например, если брак будет заключен на основаниях общего права, то в таком случае все имущество будет принадлежать исключительно мужчине.

В США так же как и в России действуют два вида режима имущества супругов: законный и договорный. Законный режим, в свою очередь, 
подразделяется на раздельную собственность и общую собственность супругов. Раздельную собственность, как правило, составляет имущество, приобретенное до заключения брака или полученное по наследству или в дар. В данном случае, имуществом каждый супруг управляет самостоятельно, однако данный факт не исключает процесс распоряжения имуществом в семейных интересах. К общей собственности можно отнести имущество, приобретенное в период брака, а также доходы супругов. Управление таким видом имущества происходит на основе равноправия супругов. Однако, стоит заметить, что не во всех штатах США действуют вышеперечисленные режимы имущества супругов.

Итак, резюмируя все вышесказанное, можно сказать, что законодательство большинства зарубежных стран предоставляют свободу выбора правового режима, который будет регулировать имущественные отношения супругов. Супруги в большинстве случаев вправе немного изменить данный режим. Так, например, зачастую супруги вправе изменить режим общей собственности, добавив положения режима ограниченной общности. Также в большинстве стран есть возможность комбинирования нескольких режимов вместе или использовать на разные виды имущества разные виды правовых режимов.

Однако законодательство Российской Федерации не может отличиться таким разнообразным выбором правовых режимов для регулирования имущество супругов и свободной возможностью выбора любого из режима, как следствие. Но стоит заметить, что данные пробелы и недочеты в законодательстве могут решиться посредством заключения брачного договора. Поскольку брачный договор предоставляет супругам вполне большие возможности для регулирования и контроля своих имущественных отношений.

\section{Список литературы}

1. Гражданский кодекс Российской Федерации (часть первая) от 30.11.1994 N 51-Ф3 (ред. от 09.03.2021) // "Российская газета", N 238-239, 08.12 .1994$.

2. Захарова С.Н. Понятие и общая характеристика имущественных правоотношений супругов // Журнал «Научный журнал». 2019.С.52.

3. Ковальчук М.Ю. Некоторые проблемы раздела общего имущества супругов в Российском праве // Сборник статей LVIII конференции научного сообщества XXI столетия. 2017. №10(57). С.58. 
4. Конституция Российской Федерации (принята // всенародным голосованием 12.12.1993, с изменениями, одобренными в ходе общероссийского голосования 01.07.2020) (с учетом поправок, внесенных Законами Российской Федерации о поправках к Конституции Российской Федерации от 30.12.2008 № 6-ФКЗ, от 30.12.2008 № 7-ФКЗ, от 05.02.2014 № 2-ФКЗ, от 21.07.2014 № 11-ФКЗ, от 14.03.2020 №1-ФКЗ) // Собрание законодательства Российской Федерации. - 04.08.2014. - № 31. - Ст. 4398.

5. Морандьер Л. Гражданское право Франции. Т. 1 / Пер. с фр. И. Громм. М.: Инфра, 2008. - С.230

6. Чужинова Ю.А. Особенности правового регулирования законного режима имущества супругов в Российской Федерации // Вестник Московского университета МВД России. 2015. № 28. С.86

(C) М.В. Сербин, Л.А. Сербина, 2021 